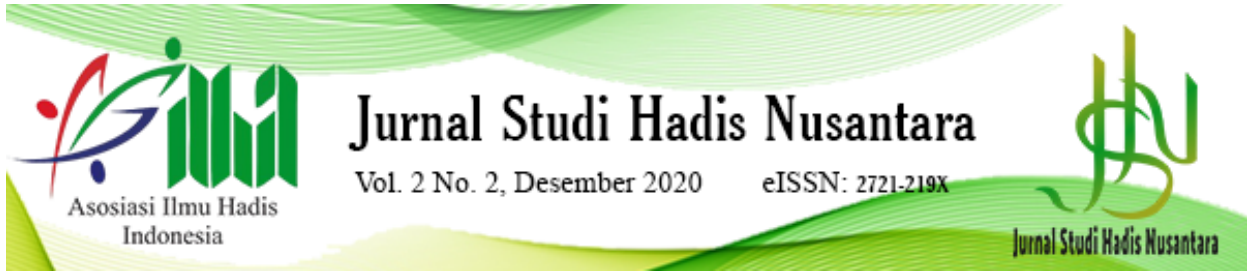

\title{
PENGANGKATAN KEPALA NEGARA PERSPEKTIF HADIS HUKUM TATA NEGARA
}

\author{
Am'mar Abdullah Arfan \\ IAIN Syekh Nurjati Cirebon \\ ammararfan@gmail.com
}

\begin{abstract}
The presidential appointment is obligatory. This is because a president can lead the fate of the life of Muslim in the future. The concept of president has no standard regulation of governing, so it can be adapted to the situation and condition surround the people as long as it does not contradict with the principle from Qur'an and Hadith. The power of president in Islamic constitution is the power that comes from people and Allah SWT.
\end{abstract}

Keywords: appointment, presidential, hadith

\begin{abstract}
Abstrak
Pengangkatan kepala negara hukumnya wajib. Hal ini karena seorang kepala negara dapat membuat terarahnya nasib kehidupan umat Islam dalam menghadapi tantangan di masa depan. Konsep mengenai kepala negara tidak ada ketentuan baku yang mengatur, sehingga dapat disesuaikan dengan situasi dan kondisi yang melingkupi umat dengan syarat tidak bertentangan dengan prinsip-prinsip yang terkandung dalam Al-Qur'an dan hadis. Kekuasaan yang dipegang kepala negara atau khailifah dalam ketatanegaraan Islam adalah kekuasaan yang berasal dari rakyat dan dari Allah SWT.
\end{abstract}

Kata Kunci: pengangkatan, kepala negara, hadis

\section{A. PENDAHULUAN}

Persoalan yang paling asasi dalam sebuah komunitas, entitas sosial, bahkan negara adalah kepemimpinan. Persoalan ini menjadi bagian dari hukum alam (sunnatullah) pada setiap makhluk hidup ciptaan Tuhan. ${ }^{1}$ Manusia sebagai makhluk Tuhan paling sempurna dalam penciptaannya dilengkapi berbagai perangkat hidup guna menjalankan misinya sebagai pemakmur bumi. Menjadi pemakmur bumi tidak dapat dilakukan sendiri.

1 Farkhani, Hukum Tata Negara (Solo: Pustaka Iltizam, 2016), h. 95 
Pemakmur bumi butuh kawan, kemampuan manajerial, dan kepemimpinan. Hal ini berguna untuk bekerja, mengorganisir, dan mengatur individu dan masyarakat dalam rangka memakmurkan bumi.

Apabila memperbincangkan sejarah peradaban manusia, maka bercerita tentang kemajuan budaya, teknologi, ilmu pengetahuan, kekuasaan, dan kejayaan sebuah kaum, dinasti, kerajaan, bangsa dan negara, atau kegemilangan ekspedisi dan invasi ataupun kolonialisasi. Kisah sejarah tidak lengkap tanpa menyertakan nama-nama pemimpinnya. Berbicara pemimpin maka akan berbicara pula tentang pola kepemimpinan, cara pemilihan, berakhirnya kekuasaan, kemudian terpilihnya pemimpin yang baru.

Kepemimpinan Islam pada zaman Nabi Muhammad SAW dimulai sejak pindah dari Mekkah ke Yathrib (Madinah). Sukar dibedakan antara petunjuk-petunjuk mana yang beliau sampaikan sebagai utusan Allah SWT dan mana yang beliau berikan sebagai pemimpin masyarakat atau kepala negara. ${ }^{2}$ Aktifitas mendasar yang dilakukan Nabi adalah membangun Masjid Quba' serta menata masyarakat yang majemuk. Ada berbagai komunitas seperti Arab Muslim dari Mekkah, Arab Madinah dari suku Aus dan Khazraj yang muslim, Yahudi, dan Arab Paganis. Nabi menempuh dua cara dalam menghadapi ini: (1) menata intern dengan mempersaudarakan kaum Anshar dan Muhajirin berdasarkan agama Islam, (2) mempersatukan kaum muslimin dengan kaum Yahudi bersama sekutu-sekutunya dengan Piagam Madinah. ${ }^{3}$ Saat terjadi musyawarah di Tsaqifah, Bani Saidah membicarakan pengganti Rasulullah dalam mengurus agama dan mengatur kedunawiaan. Orang-orang Anshar pernah berkata: "Dari kami ada Amir dan dari TuanTuan juga ada Amir). ${ }^{4}$ Di dalam sejarah Islam, gelar khalifah banyak digunakan dari pada imam, kecuali di kalangan orang-orang syi'ah. Dari empat khalifah setelah rasul, di kalangan Bani Umayyah dan Abbasiyah, Umar ibnu Khattab yang pertama menggunakan gelar Amirul Mukminin seperti halnya Abu Bakar yang pertama kali menggunakan khalifah. ${ }^{5}$

Pebedaan mengenai konsep pemerintahan Islam menjadi perdebatan panjang setelah Nabi Muhammad SAW wafat. Pada artikel ini penulis secara garis besar mengkaji masalah kepemimpinan dalam Islam serta mekanisme pengangkatam kepala negara perspektif hadis hukum tata negara.

2 Munawir, Islam Dan Tata Negara (Jakarta: UI Press, 2003), h. 16

3 Muhibbin, Hadits-Hadits Politik (Yogyakarta: Lesiska, 1996), h. 38

4 A. Djazuli, Fiqh Siyasah: Implementasi Kemaslahatan Umat Dalam Rambu-Rambu Syari'ah (Bandung: Prenada Media, 2003), h. 92

5 Ibid. h. 89 


\section{B. PEMBAHASAN}

1. Kepemimpinan dalam Islam

Dunia pemimpin dan kepemimpinan, baik yang bersifat profan maupun sakral, sangat dekat dengan persoalan politik. Sementara itu, politik bernuansa profan. Menjadi pemimpin sebuah negara, kemahiran, ketangkasan, kelihaian, keluwesan, keluasan, ketegasan, dan sikap positif dapat dengan mudah berubah sesuai kepentingan yang menghadangnya. Nilai-nilai kepemimpinan lahir dari proses perubahan karakter atau transformasi internal dalam diri seseorang. Ini menunjukkan bahwa kepemimpinan lahir dari proses panjang dalam diri seseorang.

Istilah pemimpin dalam Lisanul Arab, memakai kata alqaudu "memimpin atau menuntun" lawan dari kata as-sauqu "menggiring" seperti perkataan menuntun binatang dari depan dan menggiring binatang dari belakang. ${ }^{6}$

Para ahli manajemen memberikan pengertian pemimpin. Pemimpin dalam pengertian ini diupayakan untuk dapat dipahami oleh mereka yang sedang belajar menjadi pemimpin dan memiliki keterampilan memimpin. Menurut Ermaya Suradinata, ${ }^{7}$ pemimpin adalah orang yang memimpin kelompok dua orang atau lebih, baik organisasi maupun keluarga. Adapun Winardi ${ }^{8}$ merinci pengertian pemimpin dalam dua model pemimpin yaitu pemimpin formal (formal leader) dan pemimpin informal (informal leader). Pemimpin formal adalah seorang (pria atau wanita) yang oleh organisasi tertentu (swasta atau pemerintah) ditunjuk (berdasarkan surat-surat keputusan pengangkatan dari organisasi yang bersangkutan) untuk memangku sesuatu jabatan dalam struktur organisasi yang ada dengan segala hak dan kewajiban yang berkaitan dengannya untuk mencapai sasaransasaran organisasi tersebut yang ditetapkan sejak semula. Kepala negara termasuk dalam kategori pemimpin formal, karena dipilih dan ditetapkan dengan prosedur serta mendapatkan surat ketetapan sebagai pemimpin negara oleh lembaga yang berwenang.

Kepemimpinan memiliki kata dasar yang sama dengan pemimpin, yakni pimpin. Kepemimpinan mendapatkan awalan 'ke' dan akhiran'an' yang menjadikannya berubah menjadi kata sifat dari

6 Thariq Muhammad As-Suwaidan dan Faisahl Umar Basyrathil, Melahirkan Pemimpin Masa Depan (Jakarta: Gema Insani Press, 2005), h.9

7 Ermaya Suradinata, Manajemen Kepemimpinan (Surabaya: Pustaka Yamani, 2009), h. 11

8 Winardi, Pokok-Pokok Manajemen Organisasi (Jakarta: Pustaka Amani, 2000), h.32 
pemimpin. Artinya, kepemimpinan harus menjadi sifat dan sikap yang inheren dalam diri seorang pemimpin.

Secara terminologi, dapat dilacak beberapa pengertian tentang kepemimpinan dari beberapa orang ahli. Siagian ${ }^{9}$ berpendapat bahwa kepemimpinan adalah keterampilan dan kemampuan seseorang mempengaruhi perilaku orang lain, baik yang kedudukannya lebih tinggi mau pun lebih lebih rendah daripadanya dalam berfikir dan bertindak agar perilaku yang semula mungkin individualistik dan egosentrik berubah menjadi perilaku organisasional.

Pemimpin dan kepemimpinan dalam Islam dapat dikatakan sebagai keharusan ilahiyah dan nubuwah. Pada masa awal Islam datang, pemimpin dan kepemimpinan adalah kehendak ilahiyah. Nabi Muhammad sebagai kepala negara dan kepala pemerintahan Madinah dipersiapkan sedemikian rupa oleh Allah untuk menjadi pemimpin bagi seluruh umat manusia di dunia. Pada tataran mikro, dipahami oleh manusia sebagai pemimpin bagi umat Islam. Pada tataran mikro ini, kajian kepemimpinan Nabi Muhammad dan negara Madinah menjadi menarik dan layak menjadi kajian sepanjang sejarah manusia.

Agama Islam diturunkan Allah ke muka bumi bersama 'paket' pemimpin dan kepemimpinan. Paket ini seperti paket-paket risalah sebelumnya. Ketentuan ini sesuai dengan sunatullah yang tertera dalam beberapa firman-Nya sebagai berikut;

» "orang-orang yang kafir berkata: "Mengapa tidak diturunkan kepadanya (Muhammad) suatu tanda (kebesaran) dari Tuhannya?" Sesungguhnya kamu hanyalah seorang pemberi peringatan; dan bagi tiap-tiap kaum ada orang yang memberi petunjuk" (QS. Ar-Ra'du: 7).

" "Tiap-tiap umat mempunyai Rasul; Maka apabila telah datang Rasul mereka, diberikanlah keputusan antara mereka dengan adil dan mereka (sedikitpun) tidak dianiaya" (QS. Yunus: 47).

» "Dan (ingatlah), ketika Ibrahim diuji Tuhannya dengan beberapa kalimat (perintah dan larangan), lalu Ibrahim menunaikannya. Allah berfirman: "Sesungguhnya aku akan menjadikanmu imam bagi seluruh manusia". Ibrahim berkata: "(Dan saya mohon juga) dari keturunanku”. Allah berfirman: "Janji-Ku (ini) tidak mengenai orang yang zalim” (QS. Al-Baqarah: 124).

Pemimpin-pemimpin dalam sejarah manusia berupa utusan 9 Sondang P Siagian, Teori Dan Praktek Kepemimpinan (Jakarta: Rinneka Cipta, 2010), h. 12 
Allah (Rasul dan Nabi). Banyak diantaranya hanya berperan sebagai pemimpin spiritual bagi umatnya. Ada pula beberapa diantara mereka diutus sebagai pemimpin spiritual sekaligus sebagai pemimpin politik. Nabi Sulaiman, Nabi Daud dan Nabi Muhammad SAW adalah tiga contoh utusan Allah yang mengemban dua misi. Nabi Muhammad SAW menjadi pemimpin spiritual dan pemimpin politik Islam terakhir yang melengkapi dan menyempurnakan berbagai risalah langit yang datang sebelumnya. Ajaran Nabi Muhammad dianggap memiliki nilai universalitas dan kompleksitas dalam setiap relung kehidupan manusia. Termasuk di dalamnya landasan teologis akan urgensinya terhadap keberadaan pemimpin dalam sebuah komunitas terkecil sampai komunitas terbesar berbentuk Negara.

a. Dalil-dalil dalam Al-Qur'an

Ada 4 (empat) kata kunci yang dapat dijadikan rujukan untuk mencari dalil-dalil pemimpin dan kepemimpinan dalam al-Qur'an. Kata kuncinya adalah "imam, khalifah, wali, dan ulil amri".

I. Berkenaan dengan istilah Imam, ada dua kata yang digunakan; "imam" (isim mufrad) dan "a'immah" (isim jama'), artinya pemimpin. Kata "imam" disebut sebanyak 7 (tujuh) kali dalam 7 (tujuh) surat yang berbeda. Kata "a'immah" disebut sebanyak 5 (lima) kali dalam 4 (empat) surat.

- Kata "imam" terdapat dalam ayat-ayat sebagai berikut; al-Hijr ayat 79, Yasin ayat 12, Al-Baqarah ayat 124 , Hud ayat 17 , al-Furqan ayat 74 , al-Ahqaf ayat 12 , dan al-Isra ayat 71 .

- Kata "a'immah" terdapat dalam ayat-ayat sebagai berikut; At-Taubah ayat 12, Al-Anbiya ayat 73, Al-Qashash ayat 5 dan 41 dan As-Sajadah ayat 24.

II. Khalifah dalam kamus bahasa Arab berasal dari kata khala-fa yang memiliki arti "dibelakang, yang datang setelah, pengganti, dan pemimpin". Kata khalifah dalam terminologi politik dimaknai sebagai pemimpin negara. Istilah khalifah dalam term pemimpin negara termaktub dalam Al-Quran sebanyak 7 (tujuh) kali dalam 6 (enam) surat, yaitu AlBaqarah ayat 30 , Shad ayat 26, Al An'am ayat 165, Yunus ayat 14 dan 73, Al-A'raf ayat 69, dan Al-Naml ayat 62.

III. Kata Wali cukup banyak disebutkan dalam Al-Qur'an baik dalam bentuk mufrad (singular) maupun dalam bentuk jama' 
(plural). Kata wali yang dapat dimaknai sebagai pemimpin negara (politik) terdapat dalam surat Al-Maidah ayat 51 dan surat Al-Nisa ayat 144.

IV. Kata ulil amri hanya terulang 2 (dua) kali dalam Al-Qur'an, yakni dalam surat An-Nisa ayat 59 dan 83.

b. Dalil-dalil dalam Al-Hadits

Al-Hadis adalah sumber panduan hidup bagi seluruh aktivitas kehidupan umat Islam. Al-Hadis juga menjadi sumber panduan penyelesaian permasalahan sosial, ekonomi, politik, dan ketatanegaraan. Nabi SAW sang pemilik dan tindak suci itu diposisikan sebagai pemimpin umat, pembela kaum lemah dan tertindas, pemimpin perang, dan posisi-posisi penting dalam kehidupan sosial-politik di masyarakat Madinah. Bahkan jauh sebelum itu, kalangan Quraisy, demi untuk menghambat ajaran Islam, Nabi Muhammad SAW pernah ditawari menjadi petinggi segala kaum di masyarakat Makkah. Jadi sangatlah wajar apabila dalam hadis terdapat banyak tuntunan tentang pemimpin dan kepemimpinan serta tanggung jawabnya sebagai pemimpin, baik pemimpin bagi dirinya sendiri maupun pemimpin bagi khalayak. Berikut ini beberapa hadis yang memberikan petunjuk bahwa pemimpin dan kepemimpinan salah satu masalah krusial dalam Islam.

» Pemimpin bertanggung jawab atas kepemimpinannya

"Setiap kamu adalah pemimpin yang akan dimintai pertanggungjawaban atas kepemimpinannya. Seorang amir yang mengurus keadaan rakyat adalah pemimpin. Ia akan dimintai pertanggungjawaban tentang rakyatnya. Seorang lakilaki adalah pemimpin terhadap keluarganya di rumahnya. Seorang wanita adalah pemimpin atas rumah suaminya. Ia akan diminta pertanggungjawaban tentang hal mereka itu. Seorang hamba adalah pemimpin terhadap harta benda tuannya, ia kan diminta pertanggungjawaban tentang harta tuannya. Ketahuilah, kaтu sетиa adalah pemimpin dan semua akan diminta pertanggung jawaban tentang kepemimpinannya" (HR Muslim, 1983:1460, Hadits No.1829 kitab al-Imarah, Jilid III) Hadits ini menjelaskan 3 pokok: ${ }^{10}$

1. Pemimpin, subyeknya. Manusia harus mampu memimpin dirinya sendiri. Jadi dasar utamanya internal manusia sendiri

10 Lukman Saksono, Filsafat Kepemimpinan: Studi Komparatif(Jakarta: PT Grafikatama Jaya, 1992), h.256 
sebagai obyek kepemimpinan. Memimpin diri sendiri berarti mengupayakan berfungsinya sistem untuk menghasilkan output yang berfungsi bagi diri dan lingkungan. Jika ingin menyuruh orang lain, kita lebih dulu melakukannya. Jika akan melarang orang lain, kita lebih dulu tidak melakukannya,

2. Kepemimpinan, dinamika terapannya. Selama ini kepemimpinan dipahami sebagai ilmu dan seni mempengaruhi orang lain, agar orang lain mau secara ikhlas melakukan sesuatu sesuai keinginan atau harapan pemimpin. Dimensi ini hanya mengandung secara eksternal, sedangkan dimensi internal hilang. Padahal keduanya harus serentak, karena kepemimpinan juga untuk diri sendiri. Dari sini suri tauladan akan secara otomatis muncul. Batas antara pemimpin dengan yang dipimpin sifatnya labil (situasional), maka pada suatu waktu orang melakukan dua status saling bersamaan atau bergantian.

3. PPertanggungjawaban, resikonya. Resiko sebagai konsekuensi logis dari keberhasilan atau kegagalan. Resiko dihitung dari sampai sejauh mana nilai kepemimpinan terapan yang diharapkan bisa tercapai. Dengan kata lain, sekecil apapun, akan dihitung mendapatkan imbalan, sebagaimana tertera dalam Q.S Al-Zalzalah ayat 7-8. Pemimpin berfungsi sebagai perisai, tidak hanya berfungsi sebagai alat untuk menyerang, tetapi juga berfungsi sebagai alat untuk berlindung:

"Sesungguhnya pemimpin itu ibarat perisai yang dibaliknyya digunakan untuk berperang dan berlindung. Apabila pemimpin memerintah berdasarkan ketakwaan kepada Allah azza wa jalla dan berlaku adil, maka baginya ada pahala, apabila memerintah dengan dasar selain itu, maka dosanya akan dibalas." (HR Muslim, tt:17 No Hadits 4878 Bab Fi al-Imam)

» Kecintaan dalam persaudaraan sebagai dasar hubungan antara pemimpin dengan pengikutnya:

Dari 'Auf bin Malik, Rasulullah SAW bersabda: "Pemimpin yang baik adalah pemimpin yang mencintai kamu dan kamu mencintainya, mendoakan kamu dan kamu mendo'akan mereka, sedangkan pemimpin yang jelek adalah pemimpin yang kamu benci dan mereka membenci kamu, kamu melaknat mereka dan mereka melaknat kamu." (HR Muslim, 1983:1481, 
Hadits No.1855 kitab al-Imarah, Jilid III).

» Keharusan mengangkat pemimpin:

"Apabila terdapat tiga orang dalam sebuah perjalanan, maka hendaknya mereka menunjuk salah seorang dari mereka sebagai pemimpin. Nafi' berkata; kemudian kami katakan kepada Abu Salamah; maka engkau adl pemimpin kami." [HR. Abu Daud No.2242].

Dengan demikian, pengangkatan pemimpin perlu adanya. Alasannya menyelamatkan manusia dari kekacauan dan menyingkirkan orang bodoh berkuasa (menempatkan orang yang kredibel untuk jadi pemimpin). Jika pemimpin yang tepat terpilih, maka akan membangun dasar pijakan kepemimpinan untuk menuju tujuan yang ideal bersama.

» Tidak boleh ada dua pemimpin:

"Jika telah dilantik(diangkat) dua khalifah (raja, Presiden, pejabat, atau pemimpin), maka bunuhlah seorang di antara mereka berdua" (HR Muslim,1983:1480, No. Hadits 1853 Kitab al-Imarah, Jilid III)

Hadits ini menjelaskan dengan diangkatnya dua pemimpin, berakibat kacaunya keadaan. Pengertian tentang perintah "bunuh" merupakan kata kiasan yang menunjukkan benarbenar hal itu tidak boleh terjadi. ${ }^{11}$

» Ketaatan terhadap pemimpin:

"Mendengar dan taat kepada pemimpinnya baik dia senang atau tidak senang selama pemimpin itu tidak menyuruh melakukan maksiat. Apabila ia memerintahkan untuk melakukan maksiat, maka tidak perlu mendengarkan dan mentaatinya." (HR al-Bukhari, 1992:445, No. Hadits 7144 Kitab al-Hukm, Juz VII)

Dalam bukunya M. Quraish Shihab ${ }^{12}$ menjelaskan apabila perintah ulul amri tidak mengakibatkan kemaksiatan, maka ia wajib ditaati, walaupun perintah tersebut tidak disetujui oleh yang diperintah. Penafsiran taat dalam bahasa Al-Qur'an "tunduk" menerima secara tulus dan menemani. Ketaatan bukan sekedar melaksanakan apa yang diperintahkan, tetapi harus ikut berpartisispasi dalam upaya-upaya yang dilakukan

11 Husein Bahrevi, Himpunan Hadits Shahih Muslim (Surabaya: Usaha Offset Printing, 1987), h. 240

12 M. Quraish Shihab, Wawasan Al-Qur'an: Tafsir Maudhui Atas Pelbagai Persoalan Umat (Bandung: Mizan, 2016), h.428-429 
penguasa guna mendukung usaha-usahanya

» Pemimpin "laki-laki":

"Dari Abu Bakar r.a Rasulullah bersabda: "tidak akan pernah bahagia suatu kaum (bangsa), jika mereka menyerahkan urusan mereka kepada wanita." (HR al-Bukhari,1987:1610, No. Hadits 4163 Kitab al-Nabi SAW, Juz IV).

Penulis mencermati pendapatnya Imam Al-Mawardi ${ }^{13}$ ddalam memberi syarat yang harus dipenuhi calon kepala negara tidak mencantumkan perempuan atau laki-laki. Di antara syarat tersebut adalah: (1) keseimbangan yang memenuhi kriteria, (2) berilmu, (3) panca indra lengkap dan sehat, (4) tidak ada kekurangan dalam tubuhnya untuk gerak, (5) visi pemikiran yang baik, (6) keberanian dan melindungi rakyat, (7) nasab dari Quraisy.

» Pemimpin dari Quraisy:

Rasulullah bersabda: "Masalah ini (imamah) ada pada orangorang Quraisy, dan tiada seorangpun yang menentangnya kecuali Allah SWT, akan melemparkannya ke dalam neraka selama mereka (orang Quraisy) berpegang kepada agama". (HR al-Bukhari, 1992: 445, No. Hadits 7139 Kitab al-Hukm, Juz VII)

Permasalahan pemimpin yang mempunyai nasab dari suku Quraisy, karena adanya nash dan telah terwujudnya ijma' ulama tentang masalah itu. Hal ini menjadi perdebatan di antara ulama' mutakallimin. Golongan Syi'ah dan Ahlu al-Sunnah menghendaki imam dari Quraisy. Khawarij dan sebagian Mu'tazilah tidak mempersyaratkan demikian. Abu Bakar pada hari Saqifah dihadapan kalangan Anshar, menolak tindakan mereka yang membaiat Sa'ad bin Ubadah r.a untuk memangku jabatan Khalifah. Pendapat Dhirar membolehkan pemimpin Negara bagi semua orang adalah pendapat yang tidak dapat didengarkan, dengan sabda Rasulullah saw. ${ }^{14}$

2. Cara Pengangkatan Kepala Negara dalam Islam

Kepala negara dan pemerintahan dalam Islam diadakan sebagai pengganti fungsi kenabian dalam menjaga agama dan mengatur dunia. Pengangkatan kepala negara untuk memimpin umat Islam sebagaimana termaktub dalam dalil-dalil yang disebutkan pada bab

13 Imam Al-Mawardi, Hukum Tata Negara Dan Kepemimpinan Dalam Takaran Islam (Jakarta: Gema Insani Press, 2000), h. 18

14 Ibid, h. 18-19 
sebelumnya, menurut ijma' ulama hukumnya wajib.

Kewajiban itu dilandaskan pada rasionalitas kemanusiaan dan dapat pula berdasarkan pada syari'at. Berdasarkan rasionalitas karena manusia mempunyai kecenderungan untuk menyerahkan kepemimpinan kepada seorang pemimpin yang dapat menghalangi terjadinya kedzaliman yang menimpa mereka serta menuntaskan perselisihan dan permusuhan diantara mereka. Seandainya tidak ada pemimpin dan pemerintah, niscaya mereka hidup dalam ketidakteraturan tanpa hukum dan menjadi bangsa yang primitif tanpa ikatan. Berdasarkan syari' at karena kepala negara menjalankan tugas-tugas agama yang bisa saja rasio tidak mendorongnya dan rasio tidak mewajibkan sang pemimpin untuk menjalankannya. ${ }^{15}$ Ketika syari'at telah mewajibkan umat Islam untuk mengangkat seorang kepala negara, maka syari'at pun telah menggariskan thariqhah, cara atau metode yang harus ditempuh untuk mewujudkan perintah wajib itu.

Dalam sejarah Nabi Muhammad saw tidak memberikan tuntunSejarah Nabi Muhammad SAW tidak memberikan tuntunan tentang bagaimana suksesi yang harus dilakukan oleh umatnya untuk memilih dan mengangkat kepala negara. Nabi Muhammad SAW menyerahkan urusan ini sepenuhnya kepada umat, asalkan tidak melanggar pesan-pesan moral yang terdapat dalam Al-Qur'an danalhadis.

Kalau kita lihat dalam pengangkatan khalifah atau kepala negara pada masa khulafaurrosyidin, Abu Bakar diangkat menjadi khalifah pertama negara Islam melalui sidang musyawarah di Banu Sa'adah. Umar bin Khatab sebagai khalifah kedua diangkat menjadi kholifah dengan pencalonan. Utsman bin Affan dipilih sebagai khalifah ketiga berdasarkan pemilihan yang dilakukan oleh tim formatur dari majelis Syura. Ali bin Abi Thalib dipilih sebagai khalifah keempat berdasarkan pilihan yang dilakukan oleh sisa-sisa majelis syura. ${ }^{16}$ Dari sini dapat kita lihat bahwa sejarah pengalaman praktik pengangkatan khalifah atau kepala negara dalam Islam tidak selalu sama dan seragam.

Islam amat menekankan soal kepemimpinan. Menurut Islam, kepemimpinan manusia dalam hal ini seorang kepala negara merupakan perpanjangan kekuasaan Allah yang dibebankan di pundak

15 Ibid, h. 15

16 Abdul Qadir Djaelani, Negara Ideal Menurut Konsepsi Islam (Surabaya: Bina Ilmu, 1995), h.163-165 
para Nabi dan orang-orang pilihan-Nya. Oleh sebab itu, setiap kepala negara harus benar-benar mematuhi apa-apa yang diperintahkan oleh Allah SWT.

Nabi Muhammad saw di samping sebagai Nabi dan Rasul, juga sebagai imam (pemimpin). ${ }^{17}$ Setelah beliau wafat, umat Islam mengangkat Abu Bakar sebagai imam mereka. Oleh karena itu, logis bahwa masyarakat yang telah terbentuk dalam suatu komunitas sosial keagamaan yang sedemikian baik, telah memenuhi unsur kenegaraan, mengangkat pemimpin yang mengurus dan mengatur berbagai kepentingan administrasi dan kenegaraan. Namun, secara tegas tidak ada nash yang menunjukan tentang pengangkatan dan penggantian imam (kepala negara). Al-Qur'an hanya secara umum memberikan isyarat mengenai prinsip musyawarah dalam setiap urusan atau hal, termasuk masalah pemilihan kepala negara ini. ${ }^{18}$

Ada beberapa pendapat mengenai mekanisme pemilihan atau pengangkatan kepala negara. Taqiyuddin An-Nahbani, menjelaskan ada lima cara pemilihan khalifah atau kepala negara, yaitu: ${ }^{19}$

a. Setelah atau sebelum meninggalnya khalifah, sebelum diberhentikan, atau setelah pengunduran dirinya, hendaknya perlu berkumpul untuk mencalonkan satu atau beberapa orang yang telah ditentukan sebagai kandidat untuk menduduki jabatan kekhalifahan. Mereka yang berkumpul seperti sekelompok warga yang tinggal di wilayah pusat ibu kota, ahlul halli wal aqdi yang ada di sana, orang-orang yang mewakili suara mayoritas kaum muslimin, gerakan yang terpandang, atau yang pantas untuk mengurusi khilafah. Kemudian, mereka mencoba untuk memilih salah satu diantara mereka dengan cara apapun yang dianggap representatif.

b. Apabila seorang khalifah ajalnya telah dekat, maka khalifah melakukan musyawarah dengan ahlul halli wal aqdi atau tokoh masyarakat lainya untuk dijadikan khalifah penggantinya. Baiat atas khalifah tersebut harus dilaksankaan. Cara ini seperti yang pernah ditempuh oleh khalifah Abu Bakar. Hal ini dilakukan oleh Abu Bakar karena trauma umat atas peristiwa di Saqifah Bani

17 Muntoha, "Kriteria Kepala Negara Dalam Sistem Politik Islam (Telaah Sosio-Historis Terhadap Hadits Politik)" (Yogyakarta, 1996), h.1

18 Yusuf Musa, Politik Negara Dan Negara Dalam Islam (Surabaya: Al-Ikhlas, 1996), h. 114

19 Taqiyuddin An-Nahbani, Sistem Pemerintahan Islam (Jakarta: AL-Izzah, 1997), h.135139 
Sa'adah telah mendorong untuk mempersiapkan penggantinya. Walaupun demikian, Abu Bakar tetap meminta masukan dari para senior. Mereka akhirnya mendapatkan kandidat yakni Umar dan Ali. Setelah memperoleh kepastian pendapatnya tentang Umar, barulah beliau meminta masukan umat Islam secara terbuka. Maka, Umar bin Khattab di baiat secara penuh setelah khalifah Abu Bakar wafat.

c. Khalifah dapat menunjuk beberapa orang baik karena inisiatifnya sendiri, permintaan orang lain, permintaan rakyat, atau pihak lain. Seperti peristiwa khalifah Umar bin Khattab sebelum menghembuskan nafas terakhir sempat menunjuk beberapa penggantinya kelak. Setelah khalifah Umar wafat, beberapa orang yang telah ditunjuk tersebut segera mengadakan musyawarah, dimana hasil musyawarah memunculkan dua orang kandidat yang sama-sama mendapat dukungan kuat, yaitu Utsman bin Affan dan Ali bin Abi Thalib. Setelah musawarah, Abdurrahman bin Auf turun ke lapangan dan menanyakan kepada masyarakat satu persatu. Akan tetapi, hasilnya tetap seimbang. Kemudian, beliau menyerukan kepada seluruh rakyat, laki-laki dan perempuan, untuk datang ke masjid tempat biasanya memberikan pengumuman. Ali bin Abi Thalib tidak bersedia untuk terikat dengan kebijakankebijakan yang dibuat oleh khalifah sebelumnya (Abu Bakar dan Umar bin Khattab) sedangkan Utsman bersedia, maka yang terpilih adalah Utsman bin Affan.

d. Setelah meninggalnya seorang khalifah, sekelompok kaum muslimin atau ahlul hallid wal aqdi, atau kelompok yang mempunyai kekuatan dapat mendatangi orang yang dipercaya memegang jabatan tersebut, maka barulah dapat diambil suatu baiat secara terbuka. Suara mayoritas umat Islam telah sepakat untuk membai'at Ali sebagai pengganti Utsman bin Affan, maka dengan demikian sahlah pembaiatan terhadap khalifah Ali bin Abi Thalib.

e. Setelah negera berdiri dan di sana terdapat majelis umat yang mewakili umat Islam dalam menyampaikan suara serta mengoreksi penguasa, dimana para anggota dari kalangan muslimin yang ada dalam majelis tersebut telah melakukan pembatasan terhadap jumlah kandidat.

Menurut Imam Mawardi, mekanisme atau suksesi kekhalifahan 
tersebut dapat dilakukan dengan dua cara: ${ }^{20}$

a. PPemilihan dilakukan oleh ahlul halli wal aqdi. Hal ini didasarkan atas naiknya Utsman bin Affan sebagai khalifah atas terbentuknya dewan formatur ahlul halli wal aqdi oleh khalifah sebelumnya (Umar bin Khattab).

b. Pencalonan yang dilakukan oleh Imam atau Khalifah sebelumnya, seperti pencalonan khalifah Umar bin Khattab yang dilakukan oleh Khalifah pendahulunya (Abu Bakar Shiddiq).

Para ulama khususnya ahli sunnah, secara umum berpendapat bahwa Nabi SAW tidak menetapkan pengganti dan cara serta sistem mekanisme penggantian diri beliau (pemimpin atau kepala negara). Oleh karena itu, mereka merumuskan teori sendiri yang diambil dari praktek kaum muslimin, khususnya pada pemerintahan khulafaurrosyidin.

Sistem penunjukan kepala negara pada calon penggantinya, meskipun terdapat unsur positifnya, (seperti ketika Abu Bakar menunjuk Umar untuk menjadi khalifah setelah beliau, dengan maksud agar tercipta stabilitas dalam negeri agar terlaksana dakwah islamiyah yang pada saat itu sedang giat-giatnya dilakukan), harus diakui bahwa unsur negatif dan resikonya lebih banyak. Kondisi ini disebabkan cara dan sistem yang demikian itu tidak memberikan kebebasan kepada umat untuk menentukan pemimpin mereka sendiri. Akibat lebih jauhnya adalah bahwa sistem tersebut dapat disalah tafsirkan dan disalahgunakan.

Dengan demikian, masalah suksesi dan pemilihan kepala negara (khalifah) adalah sepenuhnya masalah umat itu sendiri. Syari'at tidak menentukan sistem dan mekanismenya. Ini berarti umat diberi keleluasaan penuh untuk menentukan sistem dan mekanismenya sendiri. Syari'at hanya memberikan ultimate goalnya, yakni terciptanya suatu ketentraman dan kemaslahatan umat secara keseluruhan. Disisi lain, caranya dapat disesuaikan dengan situasi dan kondisi yang memungkinkan untuk mewujudkan tujuan tersebut.

\section{SIMPULAN}

Kekuasaan kepala negara mencakup bidang agama dan bidang keduniaan (sebagai kepala pemerintahan dan sebagai kepala negara), khususnya ketatanegaraan umat Islam pada masa Nabi Muhmamd SAW dan khulafaurrosyidin. Istilah khalifah adalah pimpinan yang bertanggung

20 Al-Mawardi, Op cit, h. 19 
jawab tentang masalah agama dan dunia.

Mekanisme yang digunakan dalam proses pelaksanaan suksesi para khulafaurrosyidin, dapat ditempuh melalui beberapa cara:

1. Pemilihan atau pengangkatan dilakukan oleh dewan formatur ahlul halli wal aqdi atau Majelis Syura. Mereka mempunyai hak untuk memilih dan mengangkat kepala negara atau khalifah. pemilihan dan pengangkatan dibentuk dengan dua cara, pertama, oleh umat Islam melalui kedua klan atau kelompok (partai) seperti yang terjadi pada saat pemilihan khalifah (suksesi) yang pertama setelah wafatnya rasul. Kedua ahlul halli wal aqdi yang dibentuk oleh khalifah pendahulunya (kecuali pada masa Abu Bakar).

2. Pemilihan atau pengangkatan yang dilakukan dengan cara pencalonan oleh khalifah pendahulunya sebagaimana khalifah Abu Bakar yang telah mencalonkan Umar bin Khattab sebagai penggantinya sebelum beliau wafat. Hanya saja perlu digaris bawahi bahwa cara yang kedua ini, calon pengganti khalifah telah benar-benar memenuhi syarat kekhalifahan dan sesuai dengan aspirasi umat atau rakyat.

Islam, dalam hal pemerintahan, tidak memberikan ketentuan baku seperti halnya konstitusi sekarang ini. Kalau dilihat secara historis, pengangkatan kepala negara pada masa khulafaurrosyiddin dan sesudahnya (generasi pertama) ada yang dilaksanakan secara langsung dengan baiat (direct election) dan ada juga yang dilaksanakan secara tidak langsung (indirect election) dengan adanya ahlul halli wa al-aqdi. Pada masa khulafaurrosyidin masih memungkinkan untuk dilaksanakan pengangkatan kepala negara secara langsung karena penduduk belum begitu mengglobal seperti zaman modern sekarang ini.

\section{DAFTAR PUSTAKA}

Al-Mawardi, Imam. Hukum Tata Negara Dan Kepemimpinan Dalam Takaran Islam. Jakarta: Gema Insani Press, 2000.

An-Nahbani, Taqiyuddin. Sistem Pemerintahan Islam. Jakarta: AL-Izzah, 1997.

Bahrevi, Husein. Himpunan Hadits Shahih Muslim. Surabaya: Usaha Offset Printing, 1987.

Basyrathil, Thariq Muhammad As-Suwaidan dan Faisahl Umar. Melahirkan Pemimpin Masa Depan. Jakarta: Gema Insani Press, 2005.

Djaelani, Abdul Qadir. Negara Ideal Menurut Konsepsi Islam. Surabaya: Bina Ilmu, 1995.

Djazuli, A. Fiqh Siyasah: Implementasi Kemaslahatan Umat Dalam 
Rambu-Rambu Syari'ah. Bandung: Prenada Media, 2003.

Farkhani. Hukum Tata Negara. Solo: Pustaka Iltizam, 2016.

Muhibbin. Hadits-Hadits Politik. Yogyakarta: Lesiska, 1996.

Munawir. Islam Dan Tata Negara. Jakarta: UI Press, 2003.

Muntoha. "Kriteria Kepala Negara Dalam Sistem Politik Islam (Telaah Sosio-Historis Terhadap Hadits Politik).” Yogyakarta, 1996.

Musa, Yusuf. Politik Negara Dan Negara Dalam Islam. Surabaya: AlIkhlas, 1996.

Saksono, Lukman. Filsafat Kepemimpinan: Studi Komparatif. Jakarta: PT Grafikatama Jaya, 1992.

Shihab, M. Quraish. Wawasan Al-Qur'an: Tafsir Maudhui Atas Pelbagai Persoalan Umat. Bandung: Mizan, 2016.

Siagian, Sondang P. Teori Dan Praktek Kepemimpinan. Jakarta: Rinneka Cipta, 2010.

Suradinata, Ermaya. Manajemen Kepemimpinan. Surabaya: Pustaka Yamani, 2009.

Winardi. Pokok-Pokok Manajemen Organisasi. Jakarta: Pustaka Amani, 2000. 